九州大学学術情報リポジトリ

Kyushu University Institutional Repository

\title{
Diural Variation in Secretory Immunoglobulin A Concentration
}

\section{Liu, Zhongfeng}

Laboratory of Food Chemistry, Division of Applied Biological Chmistry, Department of Bioscience and Biotechnology, Graduate School of Bioresource ad Bioenvironmental Science, Kyushu University

Otonari, Michihiko

Laboratory of Food Chemistry, Division of Applied Biological Chmistry, Department of Bioscience and Biotechnology, Graduate School of Bioresource ad Bioenvironmental Science, Kyushu University

Naito, Seiko

Laboratory of Food Chemistry, Division of Applied Biological Chmistry, Department of Bioscience and Biotechnology, Graduate School of Bioresource ad Bioenvironmental Science, Kyushu University

Yasuda, Shin

Laboratory of Food Chemistry, Division of Applied Biological Chmistry, Department of Bioscience and Biotechnology, Graduate School of Bioresource ad Bioenvironmental Science, Kyushu University

他

https://doi.org/10.5109/4540

出版情報：九州大学大学院農学研究院紀要. 48 (1/2)，pp.167-174，2003-10-01. Faculty of Agriculture, Kyushu University

バージョン：

権利関係: 


\title{
Diurnal Variation in Secretory Immunoglobulin A Concentration
}

\author{
Zhongfeng LIU*, Michihiko OTONARI*, Seiko NAITO*, Shin YASUDA*, \\ Hideyuki TANAKA**, Hiroshi YOSHIOKA**, Masato OYABU**, \\ Takuro TOBINA***, Ryou KANDA****, Hiroaki TANAKA**, \\ Munehiro SHINDO**, Hirofumi TACHIBANA, \\ and Koji YAMADA ${ }^{\dagger}$
}

\author{
Laboratory of Food Chemistry, Division of Applied Biological Chemistry, \\ Department of Bioscience and Biotechnology, Faculty of Agriculture, \\ Kyushu University, Fukuoka 812-8581, Japan \\ (Received June 30, 2003 and accepted July 15, 2003)
}

\begin{abstract}
The aim of this study was to investigate the effect of time of day on secretory immunoglobulin A (sIgA). Six males participated in this study. Saliva samples were collected for each subject at 06:00, 06:30, 07:00, 07:30, 11:30, 18:00, 22:30 and 06:00 next morning on both routine diet day and prescribed diet day. SIgA concentration was determined by an enzyme linked immunosorbent assay, and total saliva protein concentration was determined by BCA protein kit. There was no significant diurnal variation for saliva flow rate in each day. SIgA concentration and secretion rate were high in the morning and low in the afternoon and evening on both days, and the levels of sIgA concentration at 18:00 and 22:30 were significantly lower than that at 06:00 next morning on the prescribed diet day. Both sIgA concentration and secretion rate had no significant difference between routine diet day and prescribed diet day. The levels of total saliva protein concentration and secretion rate at 18:00 were higher in routine diet day than in prescribed diet day. These results suggested that sIgA concentration showed diurnal variation on prescribed diet day.
\end{abstract}

Keyword: secretory immunoglobulin A, diurnal variation, protein

\section{INTRODUCTION}

Immunoglobulin A (IgA) is the predominant immunoglobullin contained in secretions of the mucosal immune system. Secretory IgA (sIgA) is found in saliva, intestinal secretions, bronchoalveolar lavage fluids, urine, tears, and other mucosal fluids (Brandtzaeg, 1985; Underdown et al., 1994). SIgA is a dimer, containing a polypeptide (J chain) that links two IgA molecules as well as a polypeptide secretory component (SC) responsible for sIgA resistance to proteolysis in an enzyme-rich environment. The molecular weight of sIgA is approximately 2.5 times greater than that of serum IgA (Underdown et al., 1994). Compared with other antibodies that bathe the mucosal surfaces, sIgA has a relatively

* Laboratory of Food Chemistry, Division of Applied Biological Chemistry, Department of Bioscience and Biotechnology, Graduate School of Bioresource and Bioenvironmental Science, Kyushu University

** Laboratory of Exercise Physiology, Faculty of Health and Sports Science, Fukuoka University

*** Laboratory of Human Performance and Fitness, Graduate School of Education, Hokkaido University

**** Laboratory of Sports Medicine, Faculty of Sports Science, Fukuoka University

${ }^{+}$Corresponding author (e-mail: Yamadako@agr.kyushu-u.ac.jp) 
short half-life (3-6 days) and a high synthesis rate [66 mg/kg/day] (Schaffer et al., 1991).

The secretory immune system of mucosal tissues such as the upper respiratory tract is considered the first barrier to colonization by pathogenic microorganisms causing upper respiratory tract infection (URTI). SIgA is a major effector of host defense against microorganisms causing URTI. IgA inhibits attachment and replication of pathogenic microorganisms, preventing their entry into the body. The level of IgA in mucosal fluids is more closely correlated with resistance to URTI than serum antibodies (Mackinnon et al., 1994). A decrease in the concentration of SIgA was considered as a possible causal factor in the increased susceptibility of athletes to URTI. SIgA has been shown to decrease during a 7-month training program in elite swimmers and correlate inversely with the number of URTI (Gleeson et al., 1999). After acute prolonged exercise, sIgA has also been shown to decrease (McDowell et al., 1992; Mackinnon et al., 1993; Steerenberg et al., 1997).

However, virtually all of physiological and psychological variables show evidence of large rhythmic changes (24hour rhythmicity), and many physiological responses to exercise are influenced by the time of day effect (Hill et al., 1992; Shephard et al., 1997). SIgA concentration has also been shown to exhibit diurnal variation with a significant decrease during the morning hours reaching a plateau by noon, thereafter, sIgA concentration remained stable (Walsh et al., 2002). So, studies show a decrease in sIgA after prolonged exercise performed in the morning cannot make clear conclusions about whether the decrease in SIgA was a result of the exercise per se or due to the passage of time (Walsh et al., 2002). We are interested in studying the effects of exercise on sIgA, and we wished to establish the effects of prolonged exercise on SIgA responses independent of any diurnal variation in sIgA. So as the first step, we investigated the effect of time of day on sIgA concentration.

\section{MATERIALS AND METHODS}

\section{Subjects and experimental protocol}

The subjects were six healthy males who were studying in Fukuoka University (22-42 years old). The aim of the study and the procedures involved were explained to the subjects before their written consent was obtained.

Six subjects were randomly divided into two groups. Saliva samples were collected for each of them on two days, without any exercise. At the first day, one group had a routine diet and another group had a prescribed diet $(1950 \mathrm{kcal} / \mathrm{d}$, protein, fat and carbohydrate: $16.6 \%, 21.5 \%, 61.9 \%$, respectively). Then, the two groups were exchanged at the third day by having the prescribed diet and routine diet, respectively. When the subjects performed the prescribed diet test, they were required to eat food at the same time and to drink water only. The subjects arrived at the laboratory after an over night fast on the testing morning. They were allowed to drink water with the exception of the 10-min period before each saliva samples was obtained.

\section{Saliva collection and assay}

Each subject was asked to swallow in order to empty the mouth, then, unstimulated whole saliva was collected over a $4 \mathrm{~min}$ period into the tubes at 06:00, 06:30, 07:00, 07:30, 11:30, 18:00, 22:30 and 06:00 next morning (n-06:00) on each test. Salivettes were cen- 
trifuged at $4700 \times g$ for $10 \mathrm{~min}$ at $4^{\circ} \mathrm{C}$. Saliva mass was recorded to the nearest milligram and samples were stored at $-30^{\circ} \mathrm{C}$ until analysis.

Secretory IgA was determined by sandwich ELISA. Each well of microtiter plates (NUNC-IMMUNO PLATE, Nunc A/S, Denmark) was coated at $37^{\circ} \mathrm{C}$ for $1 \mathrm{~h}$ with $100 \mu \mathrm{l} p e r$ well of an $\alpha$ chain specific goat anti-human IgA (Biosource, Camarillo, CA) diluted 1:1000 with coating buffer ( $0.05 \mathrm{M}$ carbonate-bicarnonate buffer, $\mathrm{pH} 9.6)$. The wells were washed three times with PBS (0.01 M phosphate buffer containing $0.15 \mathrm{M} \mathrm{NaCl}, \mathrm{pH} 7.2)$ containing $0.05 \%$ Tween-20 (Nacalai Tesque, INC. Kyoto, Japan). Unspecific binding was blocked by incubating wells with $300 \mu \mathrm{l}$ of blocking reagent, 10\% Block Ace (BA), for $1 \mathrm{~h}$ at $37^{\circ} \mathrm{C}$ or overnight at $4^{\circ} \mathrm{C}$. Plates were washed again as previously described. $50 \mu \mathrm{l}$ of standards or saliva samples diluted with $10 \% \mathrm{BA}$ were added to the wells and incubated for $1 \mathrm{~h}$ at $37^{\circ} \mathrm{C}$. Unbound IgA was removed by washing three times. $100 \mu \mathrm{l} \alpha$ chain specific goat antihuman IgA conjugated with horseradish peroxidase (Biosource, Camarillo, $\mathrm{CA}$ ) were added at dilution 1:1000 in $10 \% \mathrm{BA}$ and incubated for $1 \mathrm{~h}$ at $37^{\circ} \mathrm{C}$. After washing, $100 \mu \mathrm{l}$ of substrate buffer $\left(0.006 \% \mathrm{H}_{2} \mathrm{O}_{2}-0.1 \mathrm{M}\right.$ citrate buffer ( $\left.\mathrm{pH} 4.0\right): \mathrm{dH}_{2} \mathrm{O}: 2$, 2'-Azino-bis (3-ethylbenzothiazoline-6-sulfonic Acid) Diammonium Salt (ABTS) $=5$ : 4.5: 0.5 ) were added, and plates were incubated for several minutes at room temperature. The color reaction was stopped by the addition of $100 \mu \mathrm{l} 1.5 \%$ oxalic acid. The plates were read on a microplate reader (MPRA4, TOSHO CORPORATION, Tokyo, Japan) in dual wavelength mode ( 415 and $492 \mathrm{~nm}$ ). Control of IgA was included on each plate. To avoid interassay variability, all samples from one athlete were assayed on the same microtiter plate.

The absolute concentration $(\mu \mathrm{g} / \mathrm{ml})$ of IgA was determined by regression analysis. The relationship between known concentrations of IgA (standards) and absorbance was used to interpolate IgA concentration in the samples. The saliva flow rate in $\mathrm{ml} / \mathrm{min}$ was calculated from measurement of the saliva divided by the collection time. Saliva was weighed to the nearest $\mathrm{mg}$ and saliva density was assumed to be $1.00 \mathrm{mg} / \mathrm{ml}$. The secretion rate of IgA $(\mu \mathrm{g} / \mathrm{min})$ was calculated by multiplying the absolute concentration by saliva flow rate $(\mathrm{ml} / \mathrm{min})$.

Saliva samples were analysed for total saliva protein $(\mathrm{mg} / \mathrm{ml})$ using bovine serum albumin (BSA) as standard (BCA Protein Assay Reagent Kit, PIERCE, Rockford, IL). Saliva protein secretion rate $(\mathrm{mg} / \mathrm{min})$ was calculated by mutiplying saliva flow rate $(\mathrm{ml} / \mathrm{min})$ by saliva total protein concentration $(\mathrm{mg} / \mathrm{ml})$.

\section{Statistical}

All values are shown as means \pm SD. Statistical evaluation of the changes in the concentration of saliva constituents and saliva flow rate was carried out using repeated-measure analysis of variance (ANOVA). Post-hoc analysis was performed using the Turkey test where appropriate. The accepted level of significance was $p<0.05$.

\section{RESULTS}

\section{Diurnal variation in saliva flow rate}

Saliva flow rates were ranged from 0.13 to $0.52 \mathrm{~mL} / \mathrm{min}$ on routine diet day, and 0.15 to $0.63 \mathrm{ml} / \mathrm{min}$ on prescribed diet day at the first saliva collect $(06: 00)$. The flow rate 
increased to the top at 07:30 before the breakfast, and then decreased until the next morning on both days (Fig. 1). But there was no significant diurnal variation for saliva flow rate on each day, and no significant difference between routine diet day and prescribed diet day.

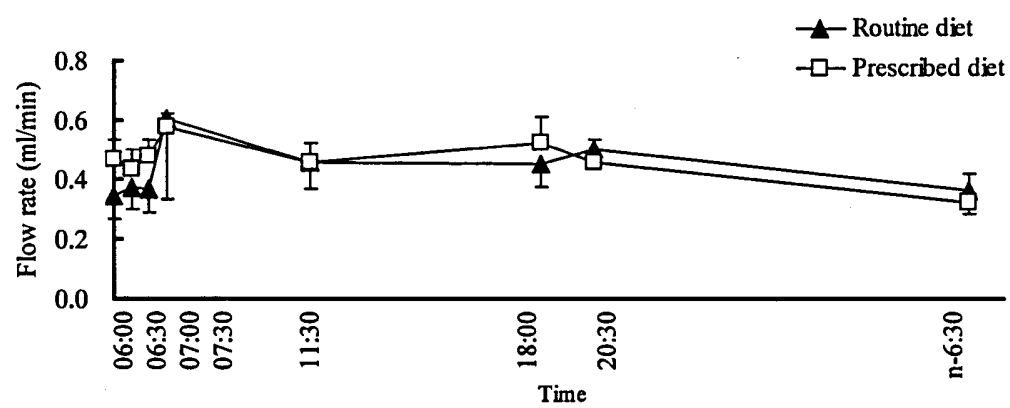

Fig. 1. Diurnal variation in saliva flow rate on routine diet day and prescribed diet day. Values are mean $\pm \operatorname{SE}(n=6)$. $\Delta$; routine diet; $\square$, prescribed diet; $\mathrm{n}-06: 00,06: 00$ at next morning.
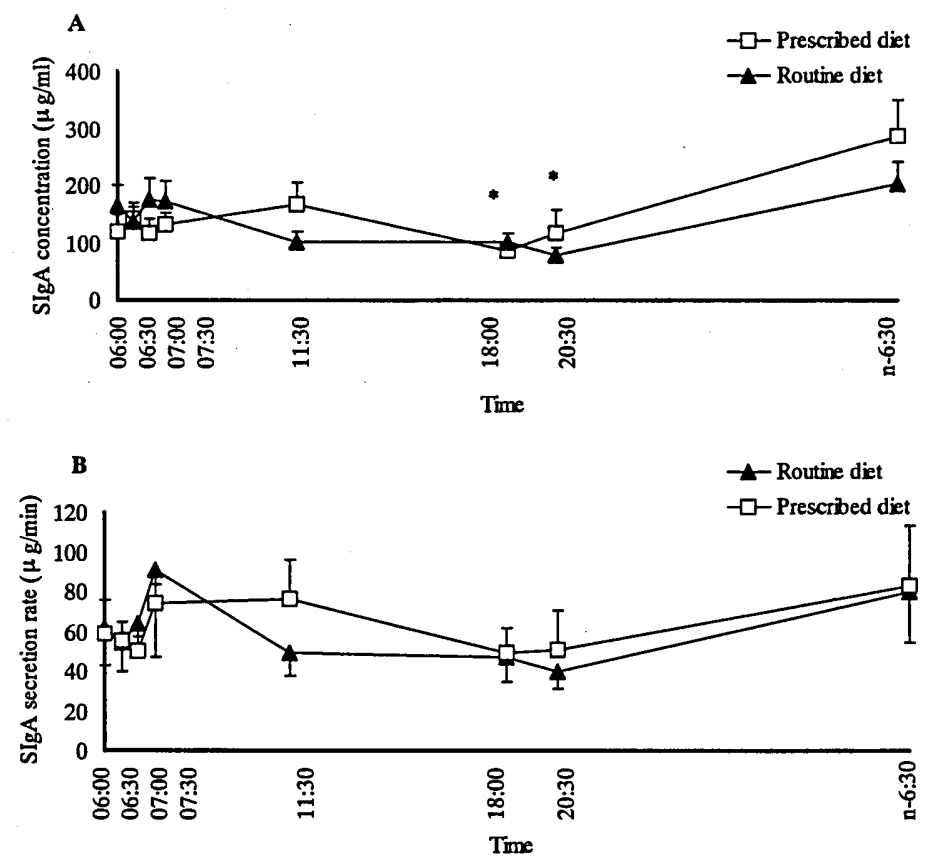

Fig. 2. Diurnal variation in $\operatorname{sig} A$ concentration (A) and secretion rate (B) on routine diet day and prescribed diet day. Values are mean $\pm \operatorname{SE}(n=6)$. $\boldsymbol{\Delta}$; routine diet; $\square$, prescribed diet; n-06:00, 06:00 next morning. Values containing an asterisk mark are significantly different from the values in $n-06: 00$ on prescribed diet day at $p<0.01$. 


\section{Diurnal variation in SIgA}

On routine diet day, sIgA concentrations were ranged from 77.29 to $201.63 \mu \mathrm{g} / \mathrm{ml}$, and were high in the morning and low in the afternoon and evening. The lowest level of sIgA concentration was shown at 22:30. On prescribed diet day, sIgA concentrations at 18:00 and 22:30 were significantly lower than that at next morning ( $n-06: 00)(p<0.01)$ (Fig. $2 A)$. SIgA secretion rate was also found to be high in the morning and low in the after-
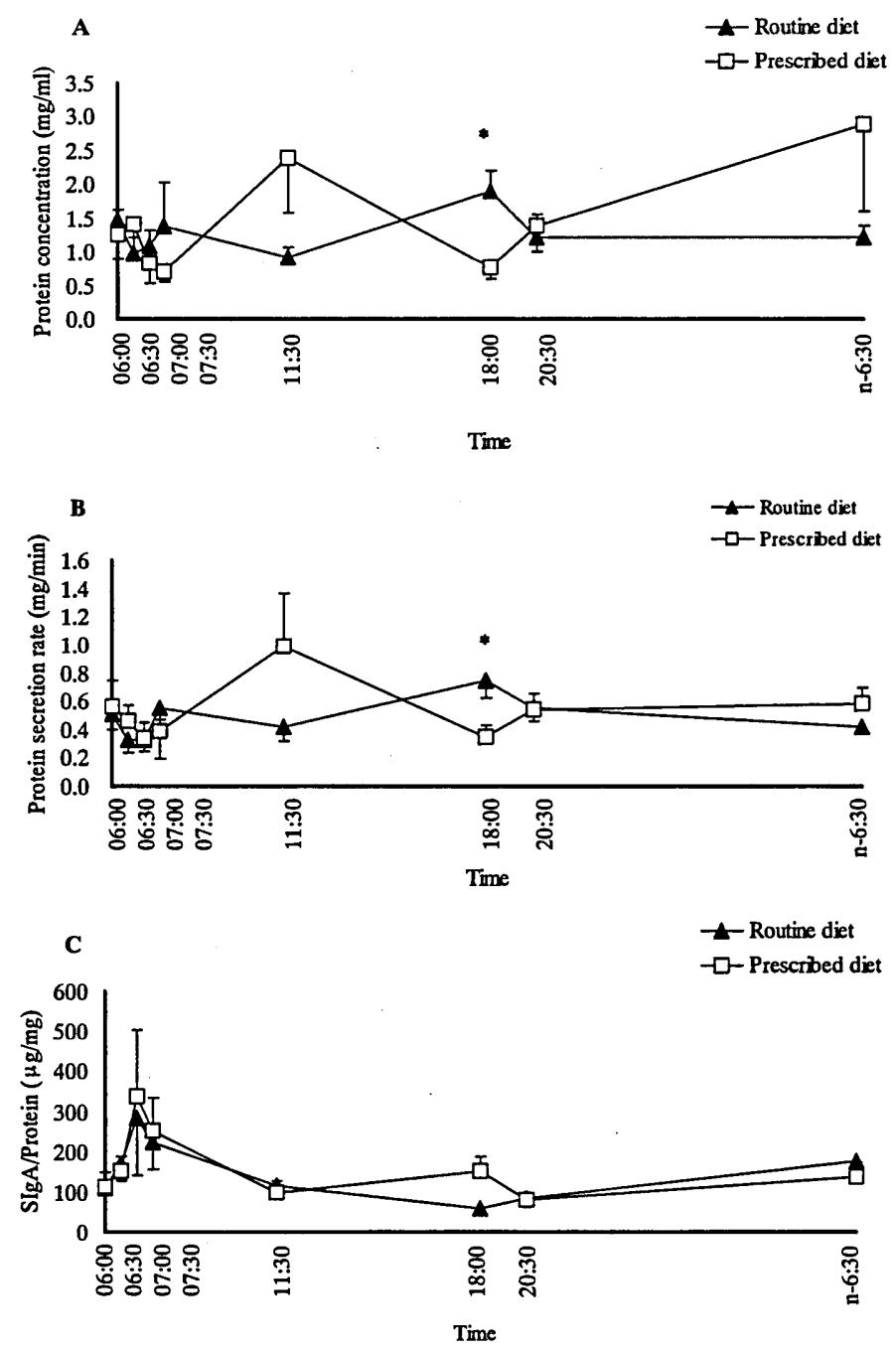

Fig. 3. Diurnal variation in total saliva protein concentration (A), protein secretion rate (B) and sIgA to protein ratio (C) on routine diet day and prescribed diet day. Values are mean $\pm \operatorname{SE}(n=6)$. $\Delta$; routine diet; $\square$, prescribed diet; $\mathrm{n}-06: 00,06: 00$ at next morning. Values containing an asterisk mark are significantly different from the values in prescribed diet day at $p<0.05$. 
noon and evening in each day. The highest levels of sIgA secretion rate were shown at 07:30 and 11:30 on routine diet day and prescribed diet day, respectively (Fig. 2B). However, there was no significant diurnal variation for sIgA secretion rate on both days. Both sIgA concentration and secretion rate did not show significant difference between routine diet day and prescribed diet day.

\section{Diurnal variation in total saliva protein}

There was no significant diurnal variation for total saliva protein concentration, protein secretion rate and sIgA to protein ratio on both days. However, the levels of protein concentration and secretion rate at 18:00 were found to be higher in routine diet day than in prescribed diet day $(p<0.05)$ (Fig. 3A, 3B), and sIgA to protein ratio also showed a peak at 07:00 on each day (Fig. 3C).

\section{DISCUSSION}

The findings of the present study agreement with the study that showed sIgA concentration was high in the morning and low in the evening (Dimitriou et al., 2002). Previous studies that determined diurnal variation in sIgA are very limited. In the study of Dimitriou et al. (2002), they also found that sIgA secretion rate and saliva flow rate were higher in the evening than in the morning in contrast with sIgA concentration. However, Miletic et al. (1996) found that sIgA secretion rate were significantly lower in the elderly than in the young, and the level of sIgA secretion rate also lower at afternoon than in morning in young person. In addition, Walsh et al. (2002) reported that a significant decrease in sIgA concentration in the morning reaching a plateau by $12: 30$, and a significant decrease in sIgA secretion rate at 10:30 reaching a plateau by 12:30.

Athletes appear to be at high risk of developing URTI during intense training and after major competition (Makinnon et al., 1994). A decrease in the concentration of sIgA was considered as a possible causal factor in the increased susceptibility of athletes to URTI (Gleeson et al., 1999). After acute prolonged exercise, sIgA has been shown to decrease (McDowell et al., 1992), increase (Schouten et al., 1988), or remain unchanged (Walsh et al., 1999). Studies on sIgA in response to exercise appear equivocal. However, many physiological responses to exercise are influenced by the time of day effect (Hill $e t$ al., 1992; Shophard et al., 1997), and the effects of time of day on the immunoendocrinological response to exercise are not clear (Trine et al., 1995). Taken together our results and previous studies suggest that experimenters wishing to determine the effects of exercise (or other factors) on the sIgA response should control for the diurnal variation in sIgA concentration (Walsh et al., 2002).

In addition, some authors express SIgA as SIgA relative to total saliva protein ratio. This accounted for changes in saliva volume that may have occurred due to drying of the oral surfaces as a result of exercise, and reflected IgA output relative to other proteins (Mackinnon et al., 1993). However, There was no significant diurnal variation for sIgA to protein ratio in this study. If sIgA is the major component of salivary protein to increase when subjects relax, expressing changes in sIgA as a secretion rate seems more appropriate than expressing sIgA in relation to changes in total protein concentration (Reid et 
al., 2001). Bishop et al. (2000) reported that carbohydrate and fluid intake influence the sIgA and saliva flow rate response to prolonged submaximal exercise. Another study suggested that the exercise-induced change in sIgA level was not affected by protein supplements (Krzywkowski et al., 2001). To investigate whether food intake affects sIgA level, we also determined the diurnal variation in sIgA with the prescribed diet to compare the routine diet. However, there was no significant difference on sIgA concentration between prescribed diet and routine diet.

Secretory IgA is the predominant salivary immunoglobulin. The primary function of sIgA is opsonization of foreign invaders at the port of entrance to the body (respiratory, gastrointestinal, vaginal, and anal mucosae) and blockade of their infectivity. This is especially important in the case of antiviral immunity in which binding of sIgA abolishes the ability of viruses to penetrate into and productively infect cells (Schaffer et al., 1991). Use of sIgA as an immune marker has numerous advantages over measurement of $\mathrm{T}$ and $\mathrm{B}$ cell in the blood. At first, compared to the blood tests, saliva collection do not have any risk for the subjects under study. Saliva is easily retrieved and can be collected as many times daily as is needed for a study. Even small children can be easily tested. Second, sIgA synthesis rate is high and half-life is short. Thus any change in sIgA concentration can be observed immediately and directly correlated with the causative agent or procedure. In addition, sIgA synthesis is $\mathrm{T}$ cell dependent and changes in synthesis can be correlated directly to $\mathrm{T}$ and $\mathrm{B}$ cell activation. At last, there is cooperation between distant compartments in the mucosal immune system, and therefore, the findings in saliva may be generalized to the entire mucosal system (Miletic et al., 1996). In conclusion, these data suggested that sIgA concentration showed diurnal variation on prescribed diet day.

\section{ACKNOWLEDGEMENT}

This work was partially supported by grants from the Japanese Ministry of Education, Culture, Sports, Science, and Technology (14380021). The authors wish to thank all of the subjects who participated in the study.

\section{REFERENCES}

Bishop. N. C., A. K. Blannin, E. Armstrong, M. Rickman, and M. Gleeson 2000 Carbohydrate and fluid intake affect the saliva flow rate and IgA response to cycling. Med. Sci. Sports Exerc., 32: 2046-2051

Brandtzaeg, P. 1985 The human secretory immune system: General revive. In: Revillard, J. P., Voisin, C., Wierzbicki, N. eds. Mucosal immunity: IgA and polymorphonuclear neutrophils. Asnieres (France): Fondation Franco Allemande; pp. 11-43

Dimitriou. L., N. C. C. Sharp, and M. Doherty 2002 Circadian effects on the acute responses of salivary cortisol and IgA in well trained swimmers. Br. J. Sports Med., 36: 260-264

Gleeson. M., W. A. McDonald, D. B. Pyne, A. W. Cripps, J. L. Francis, P. A. Fricker, R. and L. Clancy 1999 Salivary IgA levels and infection risk in elite swimmers. Med. Sci. Sports Exerc., 31: 67-73

Krzywkowski. K., E. W. Petersen, K. Ostrowski, H. Link-Amster, J. Boza, J. Halkjaer-Kristensen, and B. K. Pedersen 2001 Effect of glutamine and protein suppementation on exercise-induced decreases in salivary IgA. J. Appl. Physiol., 91: 832-838

Hill. D. W., D. O. Borden, and K. M. Darnaby 1992 Effect of time of day on aerobic and anaerobic responses to high-intensity exercise. Can. J. Sports Sci., 17: 316-319

Mackinnon, L. T., E. Ginn, and G. J. Seymour 1993 Decreased salivary immunoglobulin A secretion rate after intense interval exercise in elite kayakers. Eur. J. Appl. Physiol., 67:180-184 
Mackinnon, L. T, and S. Hooper 1994 Mucosal (Secretirt) Immune System Responses to Exercise of Varying Intensity and During Overtraining. Int. J. Sports Med., 15: S179-S183

McDowell, S. L., R. A. Hughes, R. J. Hughes, D. J. Housh, T. J. Housh, and G. O. Johnson 1992 The Effect of Exhaustive Exercise on Salivary Immunoglobulin A. J. Sports Med. Physiol. Fitn., 32: 412-415

Miletic. I. D., S. S. Schiffman, V. D. Miletic, and E. A. Sattely-Miller 1996 Salivary IgA Secretion Rate in Young and Elderly Persons. Physiol. Behav., 60: 243-248

Reid, M. R., P. D. Drummond, and L. T. Mackinnon 2001 The Effect of Moderate Aerobic Exercise and Relaxation on Secretary Immunoglobulin A. Int. J. Sports Med., 22: 132-137

Schaffer, F. M., R. C. Nibteiro, J. E. Volanakis, and M. D. Cooper 1991 IgA deficiency. Immunodef. Rev., 3: $15-44$

Schouten, W. J., R. Verschuur, and H. C. G. Kemper 1988 Habitual physical activity, strenuous exercise, and salivary immunoglobulin A levels in young adults: the amsterdam growth and health study. Int. J. Sports Med., 9: 289-293

Shephard. R. J., and P. N. Shek 1997 Interactions between sleep, other body rhythms, immune responses, and exercise. Can. J. Appl. Physiol., 22: 95-116

Steerenberg, P. A., I. A. van Asperen, A. A. van Nieuw, A. Biewenga, D. Mol, and G. J. Medema 1997 Salivary levels of immunoglobulin A in triathletes. Eur. J. Oral. Sci., 105: 305-309

Trine. M. R., and W. P. Morgan 1995 Influence of time of day on psychological response to exercise. Sports Med., 5: 328-337

Underdown, B. J., and Mestecky, J. 1994 Mucosal immunoglobulins. In: Ogra, P. L., Mestecky, K., Lamm, M. E., Strober, W., McGhee, J, R., Bienenstock, J., eds. Handbook of mucosal immunology., New York: Academic Press, Inc. 79-97

Walsh, N. P., A. K. Blannin, A. M. Clark, L. Cook, P. J. Robson, and M. Gleeson 1999 The effects of high-intensity intermittent exercise on saliva IgA, total protein and a-amylase. J. Sports Sci., 17: 129-134

Walsh, N. P., N. C. Bishop, J. Blackwell, S. G. Wierzbicki, and J. C. Montague 2002 Salivary IgA response to prolonged exercise in a cold environment in trained cyclists. Med. Sci. Sports Exerc., 26: $1632-1637$ 